\title{
PENGARUH KUALITAS PRODUK, HARGA DAN GETOK TULAR TERHADAP KEPUTUSAN PEMBELIAN PRODUK PADA TOKO PD. PESAGI JAYA TANI DI SEKINCAU LAMPUNG BARAT
}

\author{
Deny Sekti Gumelar A. \\ Denyr5178@gmail.com \\ Universitas Ahmad Dahlan \\ Fitroh Adhilla \\ fitauad@yahoo.com \\ Universitas Ahmad Dahlan
}

\begin{abstract}
ABSTRAK
This study aims to analyze the effect of product quality, prices, and infectiousness to the purchasing decision at PD Pesagi jaya farmers in West Lampung Sekincau. In this study the population used is a customer who once bought at a PD Pesagi glorious farmer. Based on the results of questionnaire data analysis of 60 customer respondents who once bought at a PD Pesagi glorious farmer using techniques non probability sampling which is a technique that does not provide opportunities or equal opportunity for each element or member of the population to be elected be sampled using purposive sampling, test instruments use validity and reliability test analysis, analysis tools with using multiple regression, hypothesis testing through $\mathrm{t}$ test and $\mathrm{F}$ test, as well as analysis of the coefficient of determination (R2). Hypothesis testing using the $t$ test shows that three variables independent studied are the variables of product quality, price, and infectiousness proven to have a positive and significant effect on the dependent variable, i.e buying decision. Then through the F test can be seen that the third independent variables are feasible to test the dependent variable decision the purchase.
\end{abstract}

Keywords: Product Quality, Price, Infectiousness, and Purchasing Decisions.

\section{PENDAHULUAN}

Perkembangan dunia usaha yang semakin pesat dewasa ini menyebabkan perusahaan harus menghadapi persaingan yang ketat, tidak sedikit perusahaanperusahaan baru bermunculan dengan menawarkan berbagai macam produk yang sangat bervariasi dan para produsen juga yang semakin kreatif dan inovatif dalam memasarkan produknya. Dengan demikian penjual atau toko-toko pengecer semakin banyak dan saling bersaing satudengan yang lain nya. Oleh karna itu, semakin banyak persaingan toko obatobatan pertanian tidak mau kalah dengan para pesaing dalam menjual produk yang dimiliki. Sebuah toko dikatakan mampu bersaing bila mampu menciptakan sebuah inovasi baru yang memberikan kepuasan bagi konsumennya, baik dari segi kualitas produk, harga dan pemasarannya, sehingga dengan demikian konsumen dapat menentukan pilihannya.

Persaingan seperti sekarang ini, perusahaan dituntut untuk menawarkan produk yang berkualitas dan mempunyai nilai lebih, sehingga tampak berbeda dengan produk pesaing. Kualitas merupakan salah satu faktor yang menjadi pertimbangan konsumen sebelum membeli suatu produk. Kualitas ditentukan oleh sekumpulan kegunaan dan fungsinya, termasuk di dalamnya daya tahan, ketidak tergantungan pada produk 
lain atau komponen lain, eksklusifitas, kenyamanan, wujud luar (warna, bentuk, kemasan, dan sebagainya). Handoko (2010) menyatakan kualitas yang bagus dan terpercaya, maka produk akan senantiasa tertanam dibenak konsumen, karena konsumen bersedia membayar sejumlah uang untuk membeli produk yang berkualitas.

Dari sudut pandang pemasaran, harga merupakan satuan moneter atau ukuran lainnya (jasa dan barang lain) yang ditukarkan agar memperoleh hak kepemilikan atau penggunaan suatu barang atau jasa (Tjiptono, 2002). Menurut Tjiptono (2007) harga itu bersifat fleksibel, artinya disesuaikan dengan cepat. Dari empat unsur bauran pemasaran tradisional, harga adalah elemen yang paling mudah diubah dan diadaptasikan dengan dinamika pasar. Ini terlihat jelas dari persaingan harga ('perang diskon') yang kerap terjadi dalam industri ritel. Menurut Tjiptono (2007) harga memainkan peranan penting bagi perekonomian secara makro, konsumen dan perusahaan.

1. Bagi Perekonomian. Harga merupakan regulator dasar dalam sistem perekonomian karena harga berpengaruh terhadap alokasi faktorfaktor produksi seperti tenaga kerja, tanah, modal, dan kewirausahaan.

2. Bagi Konsumen. Dalam penjualan ritel, ada segmen pembeli yang sangat sensitif terhadap faktor harga (menjadikan harga sebagai satu-satunya pertimbagan membeli produk) dan ada pula yang tidak.

3. Bagi Perusahaan. Dibandingkan dengan bauran pemasaran lainnya (produk, distribusi dan promosi) yang membutuhkan pengeluaran dana dalam jumlah besar, harga merupakan satusatunya elemen bauran pemasaran yang mendatangkan pendapatan.

Getok tular dapat terjadi saat memberikan pengalamannya atau bahkan sampai merekomendasikan produk tersebut kepada kerabat, keluarga maupun orang lainnya. Saluran komunikasi personal yang berupa ucapan atau perkataan dari mulut ke mulut (getok tular) dapat menjadi metode promosi yang efektif karena pada umumnya disampaikan dari konsumen oleh konsumen dan untuk konsumen, sehingga konsumen atau pelanggan yang puas dapat menjadi media iklan bagi perusahaan. Kualitas produk, harga dan getok tular ini sangat lah membantu dalam penjualan obat-obatan pertanian karna ini adalah cara yang mudah di lakukan dan gampang ditanggapi oleh petani mengingat dalam kehidupan umum petani sangat memegang teguh yang dinamakan kepercayaan. Oleh karna itu, dalam penjualan obat- obatan menjaga kualitas produk dan memberikan harg yang sesuai dengan kualitas produk itu sangat penting karna apabila petani sudah percaya dengan hal itu makan akan timbul getok tular atau biasa kita sebut promosi dari kemulut ke mulut, ini akan mempengaruhi petani yang lainnya untuk membeli produk yang ada di toko tersebut, petanipun akan mempunyai minat beli ulang produk karena sudah memiliki kepercayaan di toko tersebut.

Menurut Kotler (2013), keputusan pembelian adalah tindakan dari

konsumen untuk mau membeli atau tidak terhadap produk. Dari berbagai

faktor yang mempengaruhi konsumen dalam melakukan pembelian suatu produk atau jasa, biasanya konsumen selalu mempertimbangkan kualitas, harga dan produk yang sudah dikenal oleh masyarakat.

Mayoritas para petani di Indonesia menggunakan pupuk dan obat-obatan pestisida untuk tanamannya, banyak sekali prusahaan obat-obatan yang berkerjasama dengan pengecer atau toko obat-obatan pertanian untuk menjual produknya dan memudahkan para petani membeli pupuk dan obat pestisida yang asli. Akan tetapi, akhir- akhir ini banyak sekali toko obat-obatan pertanian yang curang mengganti produk yang bagus 
dengan produk kualitas rendah dan menjualnya dengan harga yang sama. Hal ini sangat merugikan petani yang membeli produk di toko tersebut. Disini peneliti akan meneliti pada toko PD. Pesagi Jaya Tani yang sudah menjalin kerjasama atau menjadi mitra dengan perusahaan pupuk dan obat-obatan pestisida pertanian, apakah dengan menjaga kualitas produk, menjualnya dengan harga yang sesuai dengan kualitasnya dan memasarkan produk yang dijual dengan mempromosikan dari mulut kemulut (getok tular) akan membuat konsumen membeli produk di PD. Pesagi Jaya Tani yang berpusatdi desa Sekincau Kabupaten Lampung Barat.

Tujuan dari penelitian ini di antaranya: 1) untuk menguji dan menganalisis pengaruh kualitas produk terhadap keputusan pembelian produk pada Toko PD. Pesagi Jaya Tani, 2) untuk menguji dan menganalisis pengaruh harga terhadap keputusan pembelian produk pada Toko PD. Pesagi Jaya Tani, 3) untuk menguji dan menganalisis pengaruh getok tular terhadap keputusan pembelian produk pada Toko PD. Pesagi Jaya Tani dan 4) untuk menguji dan menganalisis pengaruh kualitas produk, harga, dan getok tular terhadap keputusan pembelian pada Toko PD. Pesagi Jaya Tani.

\section{REVIEW LITERATUR DAN HIPOTESIS}

\section{Landasan Teori}

1. Pemasaran

Menurut Kotler (2011) pengertian pemasaran adalah mengidentifikasi dan memenuhi kebutuhan manusia dan sosisal. Salah satu definisi yang baik dan singkat dari pemasaran adalah memenuhi kebutuhan dengan cara yang menguntungkan.

2. Kualitas Produk

Menurut Kotler (2014) pengertian kualitas produk adalah kemampuan suatu produk untuk melakukan fungsifungsinya.

3. Harga

Definisi harga menurut Kotler (2013) adalah sejumlah uang yang dibebankan atas suatu produk atau jasa, atau jumlah dari nilai yang ditukar konsumen atas manfaat-manfaat karena memiliki atau menggunakan produk atau jasa tersebut.

4. Getok Tular (Berita Dari Mulut Ke Mulut)

Menurut Hasan (2010) getok tular merupakan pujian, rekomendasi dan komentar pelanggan sekitar pengalaman mereka atas layanan jasa dan produk yang betul-betul mempengaruhi keputusan pelanggan atau perilaku pembelian mereka. Getok tular dapat membentuk kepercayaan para pelanggan. Sedangkan Menurut Sernovitz (2009) getok tular adalah pembicaraan yang secara alami terjadi antara orang-orang. Getok tular adalah pembicaraan konsumen asli.

5. Keputusan Pembelian

Keputusan pembelian didefinisikan oleh Kotler (2014) pada tahap evaluasi, konsumen membentuk preferensi di antara merek-merek yang ada dalam pilihan dan mungkin juga merupakan niat untuk membeli merek yang paling disukai. Menurut Sumarwan (2011) keputusan pembelian adalah bagaimana konsumen memutuskan alternatif pilihan yang akan dipilih, serta meliputi keputusan mengenai apa yang dibeli, apakah membeli atau tidak, kapan membeli, dimana membeli dan bagaimana cara membayarnya. 


\section{Penelitian Terdahulu}

Akbar (2012) menganalisis hubungan antara citra merek, harga dan kualitas produk terhadap keputusan pembelian notebook Toshiba di Universitas Gunadarma Depok. Hasil penelitian menunjukkan terdapat hubungan yang signifikan antara variabel independen yaitu citra merek, harga dan kualitas produk terhadap variabel dependen yaitu keputusan pembelian.

Oktaviantika (2014) menganalisis Word Of Mouth (WOM) (Variabel Bebas) dan Minat Beli (Variabel Terikat). Hasil penelitian menunjukan bahwa variabel independen memiliki pengaruh besar terhadap Minat Beli Konsumen Pada Tune Hotels Kuta Bali.

\section{Hipotesis}

H1: Pengaruh kualitas produk terhadap keputusan pembelian.

$\mathrm{H} 2$ : Pengaruh harga terhadap keputusan pembelian.

H3: Pengaruh getok tular terhadap keputusan pembelian.

H4: Pengaruh kualitas produk, harga dan getok tular terhadap keputusan pembelian.

\section{METODE PENELITIAN}

\section{Populasi dan Sampel}

Menurut Sugiyono (2015) populasi memiliki pengertian sebagai wilayah generalisasi yang terdiri atas obyek/subyek yang mempunyai kualitas dan karakteristik tertentu yang ditetapkan oleh peneliti untuk dipelajari dan kemudian ditarik kesimpulannya. Dengan kata lain gabungan dari seluruh elemen yang berbentuk peristiwa, hal atau orang yang memiliki karakteristik yang serupa yang menjadi pusat perhatian seorang peneliti. Dalam penelitian ini populasinya adalah seluruh konsumen yang pernah membeli di toko PD. Pesagi Jaya Tani.
Menurut Sugiyono (2015) sampel adalah sebagian dari jumlah karakteristik yang dimiliki oleh populasi tersebut. Sampel ini diambil karena dalam banyak kasus tidak mungkin meneliti seluruh anggota populasi. Oleh karena itu, harus membentuk sebuah perwakilan populasi yang disebut sampel. Dalam penelitian ini sampel penelitian adalah sebagian konsumen di Sekincau Lampung Barat yang pernah membeli produk di toko PD. Pesagi Jaya Tani.

\section{Definisi Operasional}

1. Variabel Independen

a. Kualitas Produk

Menurut Kotler (2014) pengertian kualitas produk adalah kemampuan suatu produk untuk melakukan fungsi-fungsinya.

b. Harga

Definisi harga menurut Kotler (2013) adalah sejumlah uang yang dibebankan atas suatu produk atau jasa, atau jumlah dari nilai yang ditukar konsumen atas manfaatmanfaat karena memiliki atau menggunakan produk atau jasa tersebut.

c. Getok Tular

Menurut Hasan (2010) getok tular merupakan pujian, rekomendasi dan komentar pelanggan sekitar pengalaman mereka atas layanan jasa dan produk yang betul-betul mempengaruhi keputusan pelanggan atau perilaku pembelian mereka. Getok tular dapat membentuk kepercayaan para pelanggan. Sedangkan Menurut Sernovitz (2009) getok tular adalah pembicaraan yang secara alami terjadi antara orang-orang. Getok tular adalah pembicaraan konsumen asli. 
2. Variabel Dependen

Variabel dependen yang digunakan dalam penelitian ini adalah keputusan pembelian. Keputusan pembelian didefinisikan oleh Kotler (2014) pada tahap evaluasi, konsumen membentuk preferensi di antara merekmerek yang ada dalam pilihan dan mungkin juga merupakan niat untuk membeli merek yang paling disukai. Menurut Sumarwan (2011) keputusan pembelian adalah bagaimana konsumen memutuskan alternatif pilihan yang akan dipilih, serta meliputi keputusan mengenai apa yang dibeli, apakah membeli atau tidak, kapan membeli, dimana membeli dan bagaimana cara membayarnya.

\section{Uji Instrumen}

\section{Uji Validitas}

Menurut Sugiyono

validitas merupakan derajat ketepatan antara data yang terjadi pada obyek penelitian dengan daya yang dapat dilaporkan oleh peneliti. Uji validitas perlu dilakukan untuk mengetahui sejauh mana suatu alat ukur yang digunakan dalam penelitian dapat mengukur apa yang sebenarnya ingin peneliti ukur atau dapat digunakan untuk menguji instrumen penelitian agar instrumen tersebut dapat memberikan hasil sesuai dengan tujuannya.

Pengujian validitas yang dilakukan adalah construct validity dengan metode confirmatory factor analysis yang dilakukan dengan bantuan program SPSS. Analisis faktor digunakan dalam analisis penelitian ini karena merupakan salah satu metode statistik multivariate yang tujuan utamanya untuk meringkas atau mengurangi data atau variabel yang akan diperlukan untuk dianalisis. Analisis faktor memecahkan masalah yang menyangkut hubungan timbal balik antara sejumlah indikator dan kemudian menjelaskan keterkaitan antar indikator ke dalam dimensidimensi yang mendasari hubungan tersebut, dan karena item-item pertanyaan dalam kuisioner diadopsi dari penelitian sebelumnya dengan dimodifikasi, maka analisis faktor yang dilakukan bersifat confirmatory, yaitu saat pengolahan pada tahap extraction dipilih number of factor adalah 4 sesuai dengan variabel yang di uji dalam model penelitian.

Kriteria signifikansi terhadap item-item pertanyaan dalam penelitian ini didasarkan pada signifikansi praktis (practical significance) (Hair et al., 1998) seperti terlihat pada tabel berikut: Signifikansi Faktor Loading

\begin{tabular}{|c|c|}
\hline Faktor Loading & Keterangan \\
\hline Lebih besar dari 0.30 & Level minimal \\
\hline Lebih besar dari 0.40 & Sangat Penting \\
\hline Lebih besar dari 0.50 & Signifikan \\
\hline
\end{tabular}

Pedoman umum yang dipakai adalah semakin besar factor loading semakin penting indikator tersebut dalam menafsirkan suatu faktor (Hair dll., 1998). Item-item yang mempunyai factor loading kurang dari 0,40 akan dikeluarkan karena dianggap hanya mempunyai kemampuan menafsirkan suatu faktor pada level minimum. Sedangkan item yang mempunyai factor loading lebih besar dari 0,40 dianggap signifikan dan bisa dimasukkan sebagai anggota suatu faktor.

Dari hasil reliabilitas, dilakukan analisis faktor terhadap item-item yang telah memenuhi nilai reliabilitas dengan memasukkan semua item tersebut dan kemudian mengeliminasi item tersebut satu per satu bagi item yang tidak memenuhi persyaratan seperti dijelaskan sebelumnya, yaitu memiliki lebih dari satu nilai loadings yang mirip pada beberapa faktor yang berbeda, memiliki nilai loading yang lebih besar pada faktor lain dibandingkan pada faktornya, atau 
tidak memiliki nilai loading pada faktornya.

\section{Uji Reliabilitas}

Uji reliabilitas untuk menguji ketepatan instrumen pengukur dengan konsistensi diantara butir-butir pernyataan dalam suatu instrumen. Reliabilitas berkaitan dengan ketepatan prosedur pengukurandan konsistensi. Suatu alat ukur yang dinilai reliabel jika pengukur tersebut menunjukkan hasil-hasil yang konsisten dari waktu ke waktu.

Peneliti menguji instrumen penelitian dengan sampel sejumlah 60 responden. Koefisien reliabilitas ditunjukkan oleh koefisien Cronbach Alpha yang berkisar antara 0 sampai 1 . Semakin tinggi nilai koefisien Cronbach Alpha berarti semakin tinggi reliabilitas alat ukur yang digunakan. Untuk menguji reliabilitas dalam penelitian ini adalah dengan membandingkan Cronbach Coefficient Alpha ( $\mathrm{r}$ alpha) pada hasil olahan SPSS Release 24 dengan Rule of Thumb/Kesepakatan Umum dari koefisien alfa yaitu lebih besar dari 0,60 untuk penelitian eksploratori.

\section{Teknik Analisis Data}

\section{Analisis Regresi Berganda}

Ghozali (2011) berpendapat
analisis regresi pada dasarnya
dilakukan untuk mengetahui kekuatan
hubungan antara dua variabel atau
lebih. Teknik regresi cukup fleksibel
untuk menguji hubungan antar variabel
yang bersifat dependen dan memiliki
beberapa variance atau jenis sehingga
dapat diperoleh model yang paling
sesuai dengan situasi yang dihadapi.
Dalam analisis regresi, selain
mengukur tingkat hubungan antara dua
variabel atau lebih, juga menunjukkan

arah suatu hubungan antara variabel dependen dengan variabel independen. Ghozali (2011) menyebut variabel dependen diasumsikan random/stokastik yang berarti memiliki distribusi probalistik. Hubungan antara variabel dependen (Y) dan variabel independen (X) dapat digambarkan dengan persamaan sebagai berikut:

$\mathrm{Y}=\mathrm{a}+\mathrm{b} 1 \mathrm{X} 1+\mathrm{b} 2 \mathrm{X} 2+\mathrm{b} 3 \mathrm{X} 3$

Dimana:

$\mathrm{Y}=$ Kepuasan Konsumen

$\mathrm{a}=$ Konstanta

$\mathrm{b}=$ Koefisien regresi

$\mathrm{X} 1=$ Kualitas Produk

$\mathrm{X} 2$ = Harga

$\mathrm{X} 3$ = gethok tular

\section{Uji Hipotesis}

1. Uji Parsial (Uji T)

Untuk menguji kebenaran hipotesis yang digunakan dalam penelitian ini pengujian dilakukan menggunakan uji T. Menurut Ghozali (2011), uji $\mathrm{t}$ pada dasarnya menunjukkan seberapa jauh pengaruh satu variabel independen secara individual dalam menerangkan variasi variabel dependen. Pengambilan keputusan ini dilakukan berdasarkan perbandingan nilai signifikansi yang telah ditetapkan, yaitu sebesar 5\% $(\alpha=$ 0,05). Jika signifikansi lebih besar dari $\alpha$, maka Ho diterima, artinya variabel tersebut tidak berpengaruh terhadap variabel dependen. Sedangkan, jika signifikansinya lebih kecil dari $\alpha$ maka Ho ditolak yang artinya variabel independen berpengaruh terhadap variabel dependen.

2. Uji Simultan (Uji F)

Menurut Ghozali (2011), uji F pada dasarnya menunjukkan apakah semua variabel independen yang dimasukkan dalam model mempunyai 
pengaruh secara bersama-sama terhadap variabel dependen. Pengambilan keputusan ini berdasarkan perbandingan nilai $F$ hitung dengan melihat tingkat signifikansinya, kemudian membandingkan dengan taraf signifikansi yang telah ditetapkan $(5 \%$ atau 0,05). Dengan derajat keyakinan tertentu, jika $\mathrm{F}$ hitung $\leq \mathrm{F}$ tabel, maka Ho ditolak, sedangkan jika F hitung $\geq F$ tabel maka Ho diterima.

\section{Uji Koefisien Determinasi}

Koefisien determinasi $\mathrm{R}^{2}$ dimaksudkan untuk mengetahui tingkat ketepatan paling baik dalam analisa regresi dimana hal yang ditunjukan oleh besarnya koefisien determinasi $\mathrm{R}^{2}$ antara 0 (nol) dan 1 (satu). Koefsien determinasi $\mathrm{R}^{2}$ nol variabel independen sama sekali tidak berpengaruh terhadap variabel dependen. Apabila koefisien determinasi semakin mendekati satu, maka dapat dikatakan bahwa variabel independen berpengaruh terhadap variabel dependen. Selain itu koefisien determinasi $\mathrm{R}^{\mathbf{2}}$ dipergunakan untuk mengetahui prosentase perubahan variabel tidak bebas (Y) yang disebabkan oleh variabel bebas (X).

\section{HASIL PENELITIAN DAN PEMBAHASAN}

\section{Hasil Analisis Responden}

Jumlah Responden Menurut Jenis Kelamin

\begin{tabular}{|c|c|c|c|}
\hline No & Jenis Kelamin & Jumlah & Frekuensi (\%) \\
\hline 1. & Laki-laki & 43 & $71,6 \%$ \\
\hline 2. & Perempuan & 17 & $28,3 \%$ \\
\hline & Total & 60 & $100 \%$ \\
\hline
\end{tabular}

Tabel di atas dapat diketahui bahwa jumlah sampel yang berjenis kelamin lakilaki sebanyak 43 responden $(71,6 \%)$ dan jenis kelamin perempuan merupakan jumlah responden terecil yaitu sebanyak 17 orang $(28,3 \%)$.

Jumlah Responden Menurut Usia

\begin{tabular}{|c|c|c|c|}
\hline No & Usia & Jumlah & Frekuensi (\%) \\
\hline 1. & $20-29$ & 13 & $22 \%$ \\
\hline 2. & $30-39$ & 17 & $28 \%$ \\
\hline 3. & $40-49$ & 26 & $43 \%$ \\
\hline 4. & Diatas 50 tahun & 4 & $7 \%$ \\
\hline & Total & 60 & $100 \%$ \\
\hline
\end{tabular}

Tabel di atas dapat disimpulkan bahwa jumlah responden memiliki usia 20-29 adalah sebanyak 13 responden (22\%), responden yang memiliki usia 3039 adalah sebanyak 17 responden (28\%), responden yang memiliki usia 40-49 sebanyak 26 responden (43\%). Dan responden yang memiliki usia di atas 50 tahun sebanyak 4 responden (7\%).

\section{Hasil Penelitian}

1. Hasil Uji Validitas

Pada tabel di bawah ini, variabel kualitas produk memiliki empat pernyataan yang tertera di kuisioner, yaitu KP1, KP2, KP3 dan KP4. Setelah diuji validitas dengan metode CFA variabel kualitas produk menunjukkan 1 komponen dapat dilihat pada tabel component matrix di bawah ini:

Component matrix Kualitas produk

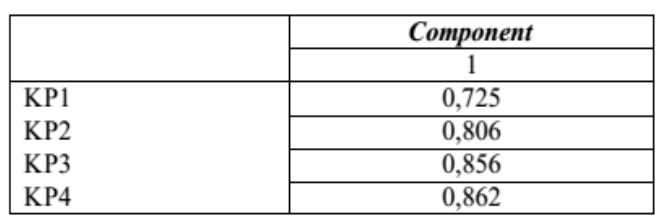

Tabel di bawah ini, component matrix variabel harga pada hasil output SPSS terlihat bahwa terbentuk 1 komponen, yang artinya item pertanyaan HG1,HG2, HG3 dan HG4 di dimana seluruh item pertanyaan tersebut dapat dinyatakan valid dan hanya menjelaskan faktorvariabel harga. 
Component matrix Harga

\begin{tabular}{|l|c|}
\hline \multirow{2}{*}{} & Component \\
\cline { 2 - 2 } HG1 & 1 \\
\cline { 2 - 2 } HG2 & 0,852 \\
\cline { 2 - 2 } HG3 & 0,831 \\
\cline { 2 - 2 } HG4 & 0,913 \\
\hline
\end{tabular}

Tabel di bawah ini, component matrix variabel gethok tular pada hasil output SPSS terlihat bahwa terbentuk 1 komponen, yang artinya item pertanyaan GT1, GT2, GT3 dan GT4 di dimana seluruh item pertanyaan tersebut dapat dinyatakan valid dan hanya menjelaskan faktor variabel getok tular.

Component matrix Gethok tular

\begin{tabular}{|l|c|}
\hline \multirow{2}{*}{} & Component \\
\cline { 2 - 2 } & 1 \\
\hline GT1 & 0,864 \\
\cline { 2 - 2 } GT2 & 0,819 \\
\cline { 2 - 2 } GT3 & 0,916 \\
\cline { 2 - 2 } GT4 & 0,890 \\
\hline
\end{tabular}

Tabel di bawah ini, component matrix variabel kepuusan pembelian pada hasil output SPSS terlihat bahwa terbentuk 1 komponen, yang artinya item pertanyaan KPB1, KPB2, KPB3 dan KPB4 di dimana seluruh item pertanyaan tersebut dapat dinyatakan valid dan hanya menjelaskan faktor variabel keputusan pembelian.

Component matrix Keputusan pembelian

\begin{tabular}{|l|c|}
\hline \multirow{2}{*}{} & Component \\
\cline { 2 - 2 } & 1 \\
\hline KPB1 & 0,705 \\
\cline { 2 - 2 } KPB2 & 0,878 \\
\cline { 2 - 2 } KPB3 & 0,782 \\
\cline { 2 - 2 } KPB4 & 0,688 \\
\hline
\end{tabular}

Dari penjelasan-penjelasan tersebut kita dapat melihat koefisien uji validitas dengan metode CFA dengan program IBM SPSS 24 for statistic dapat di lihat dari tabel di bawah ini, dimana tabel tersebut hanya menampilkan pernyataan valid. Kemudian setelah uji validitas maka dilanjutkan dengan uji reliabilitas atau kehandalan pernyataan.
Hasil Uji Validitas

\begin{tabular}{|c|c|c|c|c|c|}
\hline \multirow{2}{*}{ Indikator } & \multicolumn{4}{|c|}{ Faktor Loading } & Status \\
\hline & 1 & 2 & 3 & 4 & 4 \\
\hline KP1 & 0,725 & & & & Valid \\
\hline KP2 & 0,806 & & & & Valid \\
\hline KP3 & 0,856 & & & & Valid \\
\hline KP4 & 0,862 & & & & Valid \\
\hline HG1 & & 0,852 & & & Valid \\
\hline HG2 & & 0,831 & & & Valid \\
\hline HG3 & & 0,913 & & & Valid \\
\hline HG4 & & 0,923 & & & Valid \\
\hline GT1 & & & 0,864 & & Valid \\
\hline GT2 & & & 0,819 & & Valid \\
\hline GT3 & & & 0,916 & & Valid \\
\hline GT4 & & & 0,890 & & Valid \\
\hline KPB1 & & & & 0,705 & Valid \\
\hline KPB2 & & & & 0,878 & Valid \\
\hline KPB3 & & & & 0,782 & Valid \\
\hline LM3 & & & & 0,688 & Valid \\
\hline
\end{tabular}

2. Hasil Uji Reliabilitas

Hasil Uji Reliabilitas

\begin{tabular}{|c|c|c|c|}
\hline Variabel & $\begin{array}{c}\text { Cronbach's } \\
\text { Alpha }\end{array}$ & $\alpha$-batas & Keterangan \\
\hline Kualitas Produk $\left(\mathrm{X}_{1}\right)$ & 0,824 & 0,60 & Reliabel \\
\hline Harga $\left(\mathrm{X}_{2}\right)$ & 0,903 & 0,60 & Reliabel \\
\hline Gethok tular $\left(\mathrm{X}_{3}\right)$ & 0,890 & 0,60 & Reliabel \\
\hline Keputusan Pembelian $(\mathrm{Y})$ & 0,760 & 0,60 & Reliabel \\
\hline
\end{tabular}

Dari tabel yang telah disajikan di atas, maka di ketahui hasil uji reliabilitas dapat dijelaskan sebagai berikut:

a. Bahwa variabel kualitas produk (X1) memiliki nilai cronbach's alpha sebesar 0,824>0,60. Berdasarkan ketentuan di atas, maka indikator dalam variabel kualitas produk dinyatakan reliabel.

b. Bahwa variabel harga (X2) memiliki nilai cronbach's alpha sebesar 0,903 > 0,60. Berdasarkan ketentuan di atas masa indikatorindikator dalam variabel harga dinyatakan reliabel.

c. Bahwa variabel getok tular (X3) memiliki nilai cronbach's alpha sebesar 0,890>0,60. Berdasarkan ketentuan di atas, maka indikatorindikator dalam variabel getok tular dinyatakan reliabel.

d. Bahwa variabel keputusan pembelian (Y) memiliki nilai cronbach's alpha sebesar 0,760 > 
0,60. Berdasarkan ketentuan di atas maka indikator-indikator dalam variabel keputusan pembelian dinyatakan reliabel.

Berdasarkan hasil analisis tersebut dapat ditarik kesimpulan bahwa masing-masing variabel baik variabel independen dan variabel dependen semuanya dinyatakan reliabel dan layak untu digunakan menjadi alat ukur kuesioner di dalam penelitian ini.

3. Hasil Uji Regresi Linier Berganda

Hasil Uji Regresi Linier Berganda

\begin{tabular}{|l|r|r|}
\hline \multirow{2}{*}{ Model } & $\begin{array}{c}\text { Unstandardized } \\
\text { Coefficients }\end{array}$ & \multicolumn{1}{c|}{ Sig. } \\
\cline { 2 - 3 } & \multicolumn{1}{|c|}{ B } & \\
\hline 1 (Constant) & 0,705 & 0,092 \\
\hline KP & 0,169 & 0,204 \\
\hline HG & 0,334 & 0,001 \\
\hline GT & 0,316 & 0,011 \\
\hline
\end{tabular}

Berdasarkan hasil perhitungan komputer dengan menggunakan program IBM SPSS Statistics 24 for Windows dapat diketahui persamaan regresi berganda linear yaitu sebagai berikut:

$\mathrm{Y}=0,705+0,169 \mathrm{X} 1+0,334 \mathrm{X} 2+$ $0,316 \mathrm{X} 3$

Dari hasil persamaan regresi
linier berganda tersebut dapat
diinterpresikan sebagai berikut:

a. Koefisien regresi keputusan pembelian (Y) adalah 0,705 yang artinya apabila nilai dari variabel lainnya tetap (konstan), maka keputusan pembelian adalah sebesar 0,705, jika nilai $\mathrm{X} 1, \mathrm{X} 2$ dan $\mathrm{X} 3$ dianggap 0 maka nilai keputusan pembelian sebesar 0,705.

b. Koefisien regresi kualitas produk (X1) adalah 0,169 yang artinya setiap kenaikan ataupun penurunan kualias produk sebesar 1 satuan dan nilai dari variabel lainnya tetap (konstan), maka kualitas produk akan mengalami kenaikan ataupun penurunan 0,169 satuan. c. Koefisien regresi harga (X2) adalah 0,334 yang artinya setiap kenaikan ataupun penurunan harga sebesar 1 satuan dan nilai dari variabel lainnya tetap (konstan), maka harga akan mengalami kenaikan ataupun penurunan 0,334 satuan.

d. Koefisien regresi getok tular (X3) adalah 0,316 yang artinya setiap kenaikan ataupun penurunan getok tular sebesar 1 satuan dan nilai dari variabel lainnya tetap (konstan), maka getok tular akan mengalami kenaikan ataupun penurunan 0,316 satuan.

\section{Hasil Uji Parsial (Uji T)} Hasil uji signifikansi parsial (uji t)

\begin{tabular}{|c|c|}
\hline \multirow{2}{*}{ Variabel } & Hasil Uji \\
\cline { 2 - 2 } & Signifikansi \\
\hline Kualitas produk & 0,204 \\
\hline Harga & 0,001 \\
\hline Gethok tular & 0,011 \\
\hline
\end{tabular}

a. Variabel Kualitas Produk

Dilihat dari nilai signifikansi hitung < alpha $(0,05)$ pada tabel di atas nilai signifikansi hitung yang diperoleh sebesar 0,204. Hal ini menunjukkan bahwa nilai signifikansi hitung 0,204 >0,05, maka hipotesis $\mathrm{HO}$ diterima dan $\mathrm{Ha}$ ditolak yang berarti bahwa tidak terdapat pengaruh signifikan antara variabel kualitas produk (X1) terhadap keputusan pembelian (Y) di toko PD. Pesagi Jaya Tani Lampung Barat.

b. Variabel Harga

Dilihat dari nilai signifikansi hitung < alpha $(0,05)$ pada tabel di atas nilai signifikansi hitung yang diperoleh sebesar 0,001. Hal ini menunjukkan bahwa nilai signifikansi hitung $0,001<0,05$, maka hipotesis $\mathrm{Ha}$ diterima dan $\mathrm{H} 0$ ditolak yang berarti bahwa terdapat pengaruh signifikan antara variabel harga (X2) terhadap keputusan pembelian (Y) di toko PD. Pesagi Jaya Tani Lampung Barat. 
c. Variabel Getok Tular

Dilihat dari nilai signnifikansi hitung < alpha $(0,05)$ pada tabel di atas nilai signnifikansi hitung yang diperoleh sebesar 0,011. Hal ini menunjukkan bahwa nilai signifikansi hitung $0,011<0,05$, maka hipotesis $\mathrm{Ha}$ diterima dan $\mathrm{H} 0$ ditolak yang berarti bahwa terdapat pengaruh signifikan antaravariabel gethok tular (X3) terhadap keputusan pembelian (Y) di toko PD. Pesagi Jaya Tani Lampung Barat.

\section{Hasil Uji Simultan (Uji F)}

\section{Hasil uji signifikansi simultan (uji F)}

\begin{tabular}{|l|c|c|}
\hline \multicolumn{1}{|c|}{ Model } & F & Sig. \\
\hline Regression & 20,794 & $0,000^{\mathrm{b}}$ \\
\hline Residual & & \\
\hline Total & & \\
\hline
\end{tabular}

Berdasarkan hasil uji simultan dari tabel di atas dilihat bahwa $\mathrm{F}$ hitung sebesar 20,794 dan pada uji $\mathrm{F}$ di atas didapatkan dengan taraf signifikansi 0,05 (sig $0,000<0,05$ ), bahwa faktor kualitas produk (X1), harga (X2) dan getok tular (X3) secara bersama-sama memiliki pengaruh yang signifikan terhadap keputusan pembelian.

6. Hasil Uji Koefisien Determinasi Nilai $\mathbf{R}^{2}$

\begin{tabular}{|c|c|c|c|c|}
\hline Model & R & R Square & $\begin{array}{c}\text { Adjusted R } \\
\text { Square }\end{array}$ & $\begin{array}{c}\text { Std. Error of } \\
\text { the Estimate }\end{array}$ \\
\hline 1 & $0.726^{\mathrm{a}}$ & 0.527 & 0.502 & 0.52539 \\
\hline
\end{tabular}

Pada tabel di atas dapat dilihat bahwa nilai R2 adalah sebesar ,527. Hal ini dapat diartikan bahwa variabel independen keputusan pembelian (X1), harga (X2) dan getok tular (X3) dapat menjelaskan variabel dependen keputusan pebelian (Y) pada toko PD. Pesagi Jaya Tani Lampung Barat sebesar $52,7 \%$, sisanya $47,3 \%$ diterangkan oleh faktor lain yang tidak diteliti.

\section{Pembahasan}

1. Pernyataan hipotesis kesatu bahwa variabel kualitas produk (X1) tidak berpengaruh terhadap keputusan pembelian pada toko PD. Pesagi Jaya Tani Lampung Barat. Hal ini bisa ditunjukan dengan nilai signifikan $(P$ Value) sebesar 0,204 > 0,05 serta nilai koefisien regresi sebesar 0,169. Dengan demikian dapat disimpulkan bahwa variabel kualitas produk (X1) tidak berpengaruh signifikan terhadap keputusan pembelian pada Toko PD. Pesagi Jaya Tani Lampung Barat, dengan demikian H1 di tolak. Menurut data yang diolah oleh penulis kualitas produk tidak berpengaruh terhadap keputusan pembelian, dikarnakan adanya banyak persamaan kualitas antara toko PD. Pesagi Jaya Tani dan toko lain, biasanya setiap toko memiliki produk unggulan masing-masing banyak juga perbedaan produk dengan kualitas yang sama contoh seperti toko PD. Pesagi Jaya Tani menjual produk A dengan kualitas yang bagus, akan tetapi toko pesaing menjual produk $\mathrm{B}$ dengan kualitas yang sama dengan produk yang dijual di toko PD. Pesagi Jaya Tani ini mempengaruhi mengapa $\mathrm{H} 1 \mathrm{di}$ tolak.

2. Pernyataan hipotesis kedua bahwa variabel harga (X2) berpengaruh terhadap kualitas produk pada toko PD. Pesagi Jaya Tani Lampung Barat. Hal ini bisa ditunjukan dengan nilai signifikan (P Value) sebesar 0,001 < 0,05 serta nilai koefisien regresi sebesar 0,334. Dengan demikian dapat disimpulkan bahwa variabel harga (X2) berpengaruh signifikan terhadap keputusan pembelian pada Toko PD. Pesagi Jaya Tani Lampung Barat, dengan demikian $\mathrm{H} 2$ diterima. Ferdinand (2006) menyatakan bahwa dalam harga merupakan variabel 
keputusan yang paling penting yang diambil oleh pelanggan. Ada dua alasannya yaitu sebagai berikut :

a. Alasan psikologis, menunjukan bahwa harga merupakan indikator kualitas dan karena itu dapat dirancang sebagai salah satu instrumen persaingan yang sangat menentukan.

b. Alasan ekonomis, harga yang terjangkau (rendah) atau harga yang bersaing merupakan salah satu pemicu penting untuk meningkatkan kinerja pemasaran.

Membeli produk dengan kualitas produk yang bagus dengan harga lebih murah ini adalah yang biasanya inginkan oleh konsumen, oleh karna itu PD. Pesagi Jaya Tani menjual barang yang kualitasnya lebih bagus dengan pesaing lain akan tetapi harga yang di tawarkan lebih murah dari pesaing lainnya inilah yang menjadi alasan mengapa petani memilih membeli produk di toko PD. Pesagi Jaya Tani.

3. Pernyataan hipotesis ketiga bahwa variabel getok tular (X3) berpengaruh terhadap kualitas produk pada toko PD. Pesagi Jaya Tani Lampung Barat. Hal ini bisa ditunjukan dengan nilai signifikan ( $\mathrm{P}$ Value) sebesar 0,011 < 0,05 serta nilai koefisien regresi sebesar 0,316. Dengan demikian dapat disimpulkan bahwa variabel getok tular (X3) berpengaruh signifikan terhadap keputusan pembelian pada Toko PD. Pesagi Jaya Tani Lampung Barat, dengan demikian $\mathrm{H} 3$ diterima. Menurut Hasan (2010), getok tular merupakan pujian, rekomendasi dan komentar pelanggan sekitar pengalaman mereka atas layanan jasa dan produk yang betul-betul mempengaruhi keputusan pelanggan atau perilaku pembelian mereka. Getok tular dapat membentuk kepercayaan para pelanggan. Kualitas produk dan harga yang relatif lebih murah dari pesaing lain ini mempengaruhi pengalaman konsumen, dari pengalaman itulah konsumen menceritakan kepada orang di sekelilingnya, inilah yang terjadi di toko PD. Pesagi Jaya Tani Sekincau Lampung Barat.

4. Pernyataan hipotesis keempat bahwa kualitas produk, harga dan getok tular secara bersama-sama berpengaruh terhadap keputusan pembelian padatoko PD. Pesagi Jaya Tani Lampung Barat. Hal ini ditunjukkan dengan nilai signifikan (P Value) sebesar $0,000<0,05$. Dengan demikian dapat disimpulkan bahwa variabel kualitas produk, harga dan getok tular secara bersamaan atau simultan berpengaruh signifikan terhadap keputusan pembelian pada Toko PD. Pesagi Jaya Tani Lampung Barat, dengan demikian H4 diterima. Menurut data yang diolah oleh penulis ada pengaruh yang signifikan dalam mempengarui keputusan pembelian konsumen pada toko PD. Pesagi Jaya Tani Sekincau Lampung Barat. Konsumen cenderung untuk membeli produk ketika kualitas produk, harga dan getok tular secara bersama-sama mempengarui konsumen.

\section{KESIMPULAN DAN SARAN}

\section{Kesimpulan}

1. Berdasarkan hasil analisis uji independen sampel t-test bahwa kualitas produk tidak berpengaruh signifikan terhadap keputusan pembelian pada toko PD. Pesagi Jaya Tani Sekincau Lampung Barat.

2. Berdasarkan hasil analisis uji independen sampel t-test bahwa harga berpengaruh secara signifikan terhadap keputusan pembelian pada toko PD. Pesagi Jaya Tani Sekincau Lampung Barat.

3. Berdasarkan hasil analisis uji independen sampel t-test bahwa getok tular berpengaruh secara signifikan terhadap keputusan pembelian pada 
toko PD. Pesagi Jaya Tani Sekincau Lampung Barat.

4. Berdasarkan hasil analisis uji independen sampel t-test bahwa kualitas produk, harga dan getok tular secara simultan berpengaruh signifikan terhadap keputusan pembelian pada toko PD. Pesagi Jaya Tani Sekincau Lampung Barat.

\section{Saran}

1. Berdasarkan penilaian responden dalam penelitian ini, sebaiknya toko PD. Pesagi Jaya Tani lebih berinofasi dalam promosi dan menaikan kualitas produk serta menyetabilkan harga agar konsumennya tidak membeli ke toko selain PD. Pesagi Jaya Tani.

2. Penelitian yang akan datang diharapkan dapat megembangkan penelitian ini dengan melakukan penelitian pada faktor-faktor lain yang dapat meningkatkan minat konsumen dalam membeli obat-obatan pertanian di toko PD. Pesagi Jaya Tani Sekincau Lampung Barat.

\section{DAFTAR PUSTAKA}

Ferdinand, Augusty. (2006). Metode Penelitian Manajemen. Semarang: Badan Penerbit Universitas Diponegoro.

Ghozali, Imam. (2011). Aplikasi Analisis Multivariate Dengan Program IBM SPSS. Semarang: Badan Penerbit Universitas Diponegoro.

Hair, dkk. (1998). Multivariate Data Analysis. Fifth Edition. New Jersy: Prentice Hall, Upper Saddle River.

Handoko, T. Hani. (2010). Manajemen Personalia dan Sumber Daya Manusia. Yogyakarta: BPFE.

Hasan, Ali. (2010). Marketing dari Mulut ke Mulut. Yogyakarta: Media Pressindo.

Kotler, Philip dan Kevin Lane Keller. (2011). Manajemen Pemasaran. Edisi Pertama. Jakarta: Erlangga.
Kotler, Philip dan Kevin Lane Keller. (2013). Manajemen Pemasaran. Edisi Ketiga Belas. Jakarta: Indeks.

Kolter, Philip dan Gary Armstong. (2014). Prinsip-Prinsip Pemasaran. Edisi Kelima Belas. New Jersey: Prentice Hall.

Sernovitz, Andi. (2009). Word of Mouth Marketing: How Smart Companies Get People Talking. New York: Kaplan.

Sugiyono. (2015). Metode Penelitian Pendidikan Pendekatan Kuantitatif, Kualitatif dan R\&D. Bandung: CV. Alfabeta.

Sumarwan, Ujang. (2011). Perilaku Konsumen: Teori Dan Penerapannya Dalam Pemasaran. Bogor: Ghalia Indonesia.

Tjiptono, Fandy. (2002). Manajemen Jasa. Yogyakarta: Andi.

Tjiptono, Fandy. (2007). Strategi Pemasaran. Edisi Pertama. Yogyakarta: Andi. 